\title{
Recognition of the Ribosomal RNA Structures by Purified Nucleolar RNA Methyltransferase
}

\author{
Masanobu OBARA and Ken HigASHI \\ Department of Biochemistry, School of Medicine, University of Occupational and \\ Environmental Health, Japan. Kitakyushu 807, Japan
}

\begin{abstract}
Previously we have isolated the specific RNA methyltransferase from the nucleoli of Ehrlich ascites tumor cells. The purified enzyme was found to be specific for methylation of C.5 position of cytosine residue in ribosomal RNA in vitro (Obara, 1982b). In the present study, we have investigated the recognition mechanisms of RNA structure by this enzyme from the points of view of both primary and secondary structures. Analysis of in vitro methylation product by ribonuclease $T_{1}$ digestion indicated the methylation-site(s) was limited to a certain number of nonanucleotide. The next experiments with either Sl nuclease or actinomycin D and ethidium bromide suggested that the enzyme modified only cytidine residue in or located close to the double stranded part of RNA. On the other hand, the characterization of analogues of cytidine residue in the RNA at molecular level showed that the methylation of rRNA was inhibited by either cytidine, CDP or CTP, but little inhibition was observed in the presence of cytosine, 5-methylcytidine and CMP.
\end{abstract}

Key words: nucleoli, ribosomal RNA, methyltransferase, 5-methylcytidine, RNA structure.

(Received 12 May 1983)

\section{Introduction}

The mechanisms of action of RNA methyltransferases involving in the methylation of ribosomal RNA precursor at the post-transcriptional level remains to be clarified. In eukaryotic cells, such methylation mainly occurs at the nucleolus (Greenberg \& Penman, 1966). To understand the specificity and the function of the methylation process, the availability of the specific RNA methyltransferases is desired by many investigators.

Previously we have purified a RNA methyltransferase localized in the nucleolus of mouse tumor cells (Obara et al., 1982a) and identified the 5-methylcytidine residue as a methylation product in both $E$. coli ribosomal RNA and the hypomethylated ribosomal RNAs from mouse tumor cells (Obara et al., 1982b). For the first time, we are now in a position to set up in vitro systems to study the recognition mechanisms of RNA structure by this purified nucleolar methyltransferase. The results suggested that the methylation site was limited to the highly specific regions of rRNA and probably within or near the double stranded portion. 


\section{Experimental Procedures}

Materials: Nuclease $\mathrm{Sl}$ and ribonuclease $\mathrm{T}$ : were obtained from Boehringer Manheim and Sigma Chemical Co., respectively. Total cellular RNA and $16 \mathrm{~S}$ ribosomal RNA from Escherichia coli were prepared as described previously (Obara et al., 1982a). 5Methylcytidine was a product of P-L Biochemicals, Inc. All the other chemicals used were of analytical grade.

Assay for methyltransferase activity: The conditions for the standard assay were followed (Obara et al., 1982a). The preparation of $\left[{ }^{3} \mathrm{H}\right]$-methyl labeled RNAs was also carried out under the same conditions unless otherwise indicated.

Nuclease S1 digestion: Total E. coli RNA $(6 \mu \mathrm{g})$ labeled by the purified nucleolar methyltransferase with S-adenosyl-L-[methyl $\left.{ }^{3} \mathrm{H}\right]$ methionine was digested with the nuclease S1 $\left(2 \times 10^{2}\right.$ units) during the appropriate times indicated in the figure in the buffer $(0.4 \mathrm{ml})$ consisting of $10 \mathrm{mM} \mathrm{AcOH}-\mathrm{AcONa}, \mathrm{pH} 5.0,0.1 \mathrm{M} \mathrm{NaCl}$ and $0.5 \mathrm{mM} \mathrm{ZnSO}$, and then 2 vols of ice-cold $0.5 \mathrm{~N}$ perchloric acid was added. The aliquots of the acid-soluble fraction obtained after the centrifugation of the mixture were counted for radioactivity in toluene-based scintillation fluid reported previously (Higashi et al., 1975).

Analysis of ribonuclease $T$, digests: The $16 \mathrm{~S}$ ribosomal RNA was used as substrates for the purified nucleolar methyltransferase. This methylated RNA was completely digested with ribonuclease $T_{1}$. The subsequent separation of the digests was carried out on polyacrylamide gel electorophoresis under denaturing conditions (Maxam \& Gilbert, 1977). The gel was sliced and solubilized with NCS reagent (Amershan) to count the radioactivity (Zaitlin \& Hariharasubramanian, 1970).

\section{Results and Discussion}

It is likely that the nucleolar methyltransferase studied in this paper recognizes the precise RNA sequence serving as site(s) for methylation since the enzyme does not methylate the naturally occurring homologous RNAs such as 18S, 28S rRNA and 45S rRNA precursor from mouse tumor cells but does methylate the same RNA with hypomethylated bases, which were obtained after cycloleucine treatment (Obara et al., 1982a). In the model experiments with $E$. coli $16 \mathrm{~S}$ rRNA we wanted to determine the adjacent sequences of the methylation. First of all, the 16S rRNA was methylated in vitro by the purified enzyme and then completely digested with ribonuclease $T_{1}$ to determine which isoplith contain $\left[{ }^{3} \mathrm{H}\right]$-methyl groups after the polyacrylamide gel electrophoresis. The main product(s) migrated at the position corresponding to 9 bases in length which was determined from the mobility of two dyes (Fig. 1). If the methylation occurs randomly at the various cytidine residues in the $16 \mathrm{~S}$ rRNA, the profile shown in Fig. 1 can not be expected. Therefore, we concluded that the nucleolar enzyme non-randomly methylates 


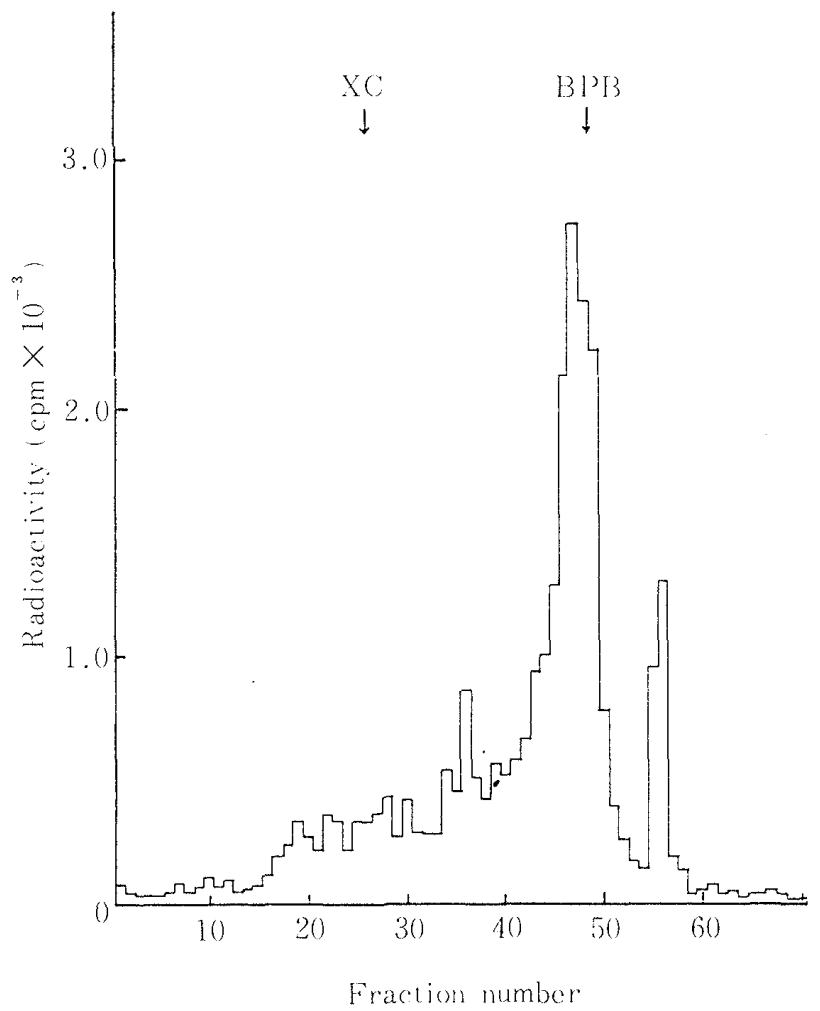

Fig. 1. Analysis of ribonuclease T/ digests of E. coli $16 \mathrm{~S}$ rRNA methylated by the purified nucleolar methyltransferase. The distribution of $\left[{ }^{3} \mathrm{H}\right]$-methyl labeled fragments was evaluated by polyacrylamide gel electrophoresis. The gel $(20 \%)$ was run under denaturing conditions and the dye markers, $\mathrm{XC}$ and $\mathrm{BPB}$, indicated the position of the xylene cyanol (27 bases in length) and bromophenol blue (8 bases in length), respectively.

the cytidine residue(s) in a limited number of sequence(s). The methylation site and its adjacent base sequence of this product(s) have not yet been fully elucidated because to carry out an autoradiography the specific activity of tritium was too low. The specific activity of the $\left[{ }^{3} \mathrm{H}\right]$-methyl group per RNA suggested only one site per rRNA molecule (data not shown). The number of isoplith of nonanucleotide out of the total ribonuclease $T_{1}$ digests of $E$. coli $16 \mathrm{~S}$ rRNA is counted up to thirteen from the primary sequence which had been determined by Brosius et al. (1978). The percentage of total length of the isoplith $(9 \times 13=117$ bases) to the full length of the RNA (1542 bases) is about 8 per cent and probably one of the isoplith was methylated by purified nucleolar methyltransferase specifically. On the other hand, the position of the main methylation-product in the secondary structure model proposed by Woese et al. (1980) is not elucidated by these analyses as described above. We then planned the following experiments to discriminate the methylation site(s) either in single-stranded or double-stranded regions of the rRNA. Ethidium bromide and actinomycin D employed in these experiments are the double-stranded region directed ligands, even with RNA. The ethidium bromide completely inhibited the methylation of RNA by the purified methyltransferase, while actinomycin $\mathrm{D}$ partially inhibited the reaction even in the presence of a higher concentration 
Table 1. Inhibition of RNA methylation by doublestrand specific ligands. Under the standard assay conditions the level of methylation in the presence of the chemicals listed was measured.

\begin{tabular}{lcc}
\hline \multicolumn{1}{c}{ Ligand } & $\begin{array}{c}\text { Concentration } \\
(\mu \mathrm{g} / \mathrm{ml})\end{array}$ & $\begin{array}{c}\text { Methylation } \\
(\%)\end{array}$ \\
\hline None & & 100 \\
Actinomycin D & 12.5 & 41 \\
& 125 & 40 \\
Ethidium bromide & 10 & 101 \\
& 100 & 2 \\
\hline
\end{tabular}

Table 2. The effect of compounds containing cytosine on the methylation. Standard assay conditions were used. The reaction mixture contained $2 \mathrm{mM}$ of chemicals listed.

\begin{tabular}{lc}
\hline Compound & Methylation (\%) \\
\hline $\mathrm{H}_{2} \mathrm{O}$ & 100 \\
Cytosine & 94 \\
Cytidine & 52 \\
5-- Methylcytidine & 93 \\
Cytidine-5'-monophosphate & 101 \\
Cytidine-5'-diphosphate & 58 \\
Cytidine-5'-triphosphate & 20
\end{tabular}

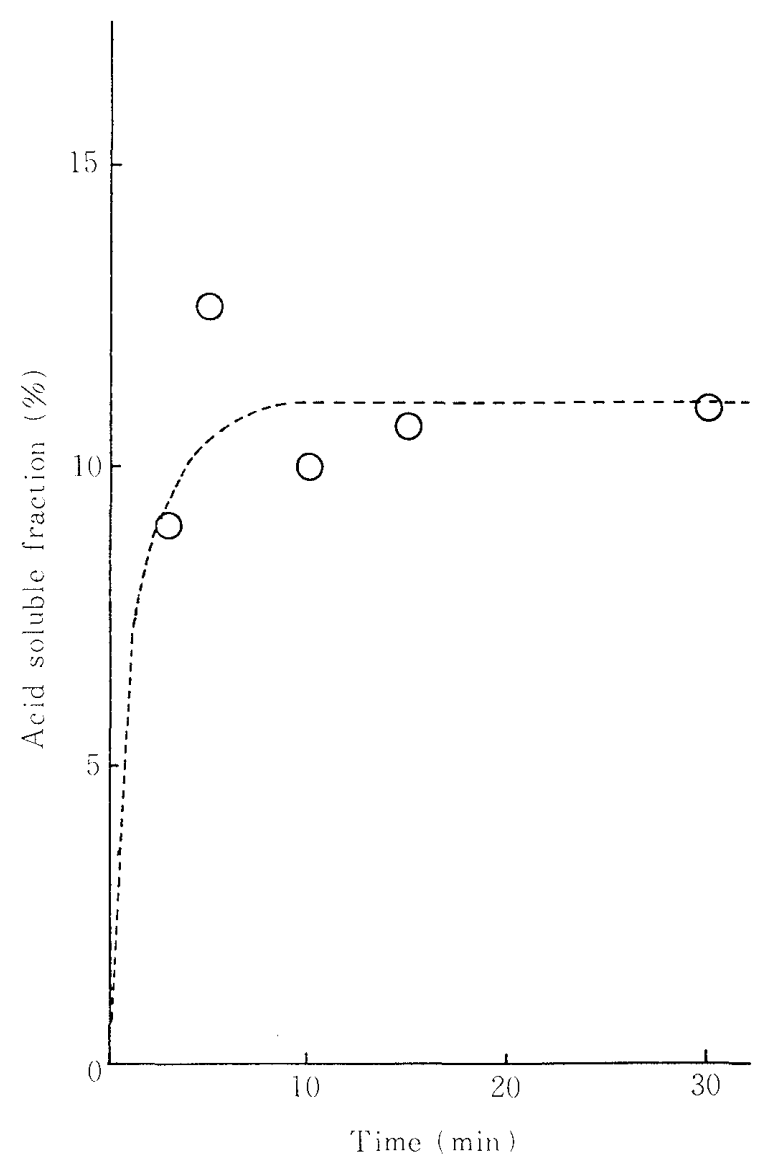

Fig. 2. The release of $\left[{ }^{3} \mathrm{H}\right]$-methyl groups from the product by nuclease Sl digestion. The methylation of total $E$. coli RNAs by purified enzyme was carried out as described in experimental procedures. The single-stranded regions of the methylated products were digested with nuclease $\mathrm{Sl}$ and were subsequently evaluated as an acid-soluble fraction. 
of the drug (Table 1). The difference of the effects of these chemicals on the methylation reaction cannot be clarified at the present time, but these results support the presence of methylation site(s) within or near the double-stranded regions of rRNA. Furthermore, we confirmed the above possibility by the experiment with nuclease $\mathrm{Sl}$, which is shown in Fig. 2. The in vitro $\left[{ }^{3} \mathrm{H}\right]$ methylated rRNA was prepared as described in the experimental procedures and used as substrates for nuclease Sl. The plateau level of the digestion was attained within $10 \mathrm{~min}$ after the start of the reaction and the release of the radioactivity from the methylated product by nuclease Sl digestion was about 10 percent at best. This result also indicated the major methylation site in the RNA did not exist in single-stranded regions.

Next, several compounds that could be considered analogues of the part of the methyl acceptors were also examined to see how the purified methyltransferase recognizes the structure of substrate. These chemicals and their effects on the methylation are summarized in Table 2. The methylation product, 5-methylcytidine, did not reduce the reaction like the base, cytosine. Possibly the binding of the enzyme to the product containing 5-methylcytidine is very weak. On the contrary, cytidine, CDP and CTP reduced the methylation in this order, probably by interfering with the binding for the cytidine residue in the $16 \mathrm{~S}$ rRNA on the enzyme. Especially the charge effect of the CTP may be more important for the inhibition than CMP or CDP. These data suggest that the nucleolar RNA methyltransferase will recognize that the nucleoside and not a part of the bases is to be methylated.

In summary, we studied the mechanism for recognizing the specific methylation site(s) by using the purified nucleolar enzyme and revealed that the preferential methylation occurred at the double-stranded regions of $E$. coli RNAs. In general, a doublestranded structure of nucleic acid, either RNA or DNA, could be recognized with much higher specificity than the same length of base sequence in single-stranded form, for example, aminoacyl tRNA synthetase or almost all of the restriction endonucleases.

\section{Acknowledgement}

This work was supported in part by a grant from the Fukuoka Cancer Society.

\section{References}

Brosius, J., Palmer, M. L., Kennedy, P. J. et al. (1978) : Complete nucleotide sequence of a $16 \mathrm{~S}$ ribosomal RNA gene from Escherichia coli. Proc. Natl. Acad. Sci. USA., 75: 4801-4805.

Greenberg, H. \& Penman, S. (1966) : Methylation and processing of ribosomal RNA in Hela cells. J. Mol. Biol., $21: 527-535$.

Higashi,K., Hanasaki, N., Schikichi, K. et al. (1975) : Ribosomal genes of the fractionated chromatin of nucleoli from Ehrlich ascites tumor cells. Cell Struct. Funct., 1:71-79.

Maxam, A. M. \& Gilbert, W. (1977) : A new method for sequencing DNA. Proc. Natl. Acad. Sci. 
USA., $74: 560-564$.

Obara, M., Hirano, H. \& Higashi, K. (1982a) : Purification and characterization of nucleolar ribonucleic acid methylase from Ehrlich ascites tumor cells of mice. Biochemistry, 21: 1374-1380.

Obara, M., Kuchino, K. \& Higashi, K. (1982b) : Isolation of nucleolar methylase producing only 5methylcytidine in ribosomal RNA. Biochem. Biophys. Res. Comm., 104: 241-246.

Woese, C. R., Magrum, L. J., Gupta, R. et al. (1980) : Secondary structure model for bacterial RNA : Phylogenetic, cnzymatic and chemical evidence. Nucleic Acids Res., 8 : 2275-2293.

Zaitlin, M. \& Hariharasubramanian, V. (1970): An improvement in a procedure for counting tritium and carbon-14 in polyacrylamide gels. Anal. Biochem., 35: 296-297.

核小体 RNA メチル基転移酵素によるリボソーム RNAの構造の識別

小原 政信・東監

産業医科大学生化学教窒

要旨： 本研究は我々が以前にマウスの腹水癌細胞より単離精製した RNAメチル基転移酵素 (cytosine 塩基の 5 位のみを選択的にメチル化する) が，その基質であるりボソーム RNA (rRNA)のメチル化部位を認識する分子機構について, rRNAの一次および二次構造上か ら検討を加えたものである。 in vitroで上記酵素でメチル化したrRNAをRNase T 1 もし くは nuclease S1を用いて分析し，更に核酸の二本鎖部分に特異的に作用する ethidium bromide と actinomycin Dのメチル化反応に及ぼす効果を調べた。これらの結果は本醉 素が rRNAの二本鎖構造内もしくはそれに近接した部位で，かつ，特定の塩基配列（9塩 基長) 內に位置する cytosine 塩基のみを非常に高い特異性をもってメチル化する事を示 していた。他方，cytosineのアナローグを用いた害験結果から本酵素は基質部位を， rRNA 内の塩基のみの違いではなく，更に糖まで含めた nucleoside のレベルで識別して いる可能性が示唆さ机た。

J. UOEH (産業医大誌)， $5(3): 337-342$ (1983) 